\title{
DISABLED MASCULINITY AS A METAPHOR OF NATIONAL CONFLICT IN THE COLD WAR ERA: ORSON WELLES' THE LADY FROM SHANGHAI (1947)
}

\author{
LEONOR ACOSTA BUSTAMANTE. \\ Universidad de Cádiz \\ leonor.acosta@uca.es
}

Received 31 July 2019

Accepted 7 January 2020

\section{KEYWORDS}

Disabled masculinities, film noir, Cold War, Orson Welles.

\section{PALABRAS CLAVE}

Masculinidades discapacitadas, cine negro, Guerra fría, Orson Welles.

\begin{abstract}
Resisting censorship and American optimism in the postwar era, film noir emerged with some specific particularities which made the genre a countercultural phenomenon in the late 1940s. The possibilities offered by these films captured the attention of Orson Welles for their display of sexual dramas as metaphors of social anxieties of the times. The renovation of the noir canon is accomplished in Welles' first noir, The Lady from Shanghai (1947), with the intention of exploring deficient masculinities surrounding the totemic power of the femme fatale. The analysis of these masculinities points out the historic and cultural context of the Cold War, an era characterized by fear and paranoia, whose effect on masculinity ends with the decomposition of any heroic stand and the loss of any kind of patriotic faith.
\end{abstract}

\section{RESUMEN}

Como resistencia a la censura y al optimismo típico de la era de posguerra, el cine negro emergió poseyendo algunas particularidades específicas que lo transformaron en un fenómeno contracultural en la década de los cuarenta en Estados Unidos. Las posibilidades que ofrecian estas películas llamaron la atención de Orson Welles por el despliegue de dramas sexuales como metáforas de las inquietudes de la sociedad de su tiempo. Welles aborda la renovación del canon establecido por el cine negro en su película La dama de Shanghai (1947), con la intención de explorar varias masculinidades 
deficientes que giran en torno al poder totémico de la mujer fatal. El análisis de estas masculinidades apunta al contexto históricocultural de la Guerra Fría, una era caracterizada por el miedo y la paranoia, con efectos sobre la masculinidad llegando a la descomposición de cualquier postura heroica y la pérdida de toda fe patriótica.

\section{FILM NOIR: THE POSTWAR PERIOD AND THE CRISIS OF MASCULINITY}

In the post-war period, the hegemonic propaganda of American optimism and welfare was counteracted by the emergence of a series of films centered on crime, degeneration, and destabilization of the bourgeois system underlying national identity. Significantly enough, the Hollywood teams creating the so-called film noir were mostly European exiles with a transnational vision that provided them with a political position divorced from the didacticism of other productions. They also had a different experience in the creative process of translating stories into images, with the evident influence of German Expressionism and other experimental techniques connected to the European avant-garde. With these two foundational axes (political and aesthetic), the new film genre filled the American theatres with complex plots about the hidden criminal underground of American cities. As in Ken Hillis' interpretation of film noir in his article "Film Noir and the American Dream: The Dark Side of Enlightenment." the male leading characters in this genre reflect an existential, often despairing, awareness of the impossibility of their own enlightenment which, unable to escape from the overall criminal milieu, cannot embrace the prospects of the American national project (3). Expressionist shadows are conventionally used to symbolize immorality and social failure in films such as The Maltese Falcon (Huston, 1941), Murder, My Sweet (Dmytryk, 1944), Double Indemnity (Wilder, 1944), Mildred Pierce (Curtiz, 1945), The Dark Corner (Hathaway, 1946), Dark Passage (Daves, 1947), The Naked City (Dassin, 1948), Fear in the Night (Shane, 1947), Out of the Past (Tourneur, 1947),D.O.A. (Maté, 1950), The Big Heat (Lang, 1953), and The Big Combo (Lewis, 1955) among many.

The link between film noir and what James Naremore calls European Modernism ("American Film Noir: The History of An Idea") tested not only the audience but also the studios' politics because the genre revealed the power of cinema in creating a psychological 
Disabled Masculinity as a Metaphor of National Conflict in the Cold War Era: Orson Welles' The Lady From Shanghai (1947)

mood through the use of symbols, expressionist scenarios and metaphorical characterization to develop plots about institutional, social, political, and sexual corruption. The land of opportunities, which was the thematic core of all other film genres in the late 1940s, was turned on its head in these texts with intense pessimism and a skeptical view of the future (Shrader 54-55). The phenomenon of film noir could be seen as a means to interrogate the shift in national identity, a new nation promoting a self-contained system of consumerism with an inaccessible frontier and a nationalist pride about being the greatest nation on Earth. In other words, Hollywood witnessed the shift from the socialist experiment projected by the New Deal to the emergence of aggressive capitalism and conservative politics; and a major testing experience was film noir. While the political scenario of the time was strongly conditioned by the Red Scare and the shift towards being a neoconservative society, film noir became the unconscious critique of American propaganda, the other side of the coin. Furthermore, the foreign accent of the European exiles working in these films provided Hollywood with a political leftish bias which was to be repressed and almost extinguished over time (Naremore, More Than Night 104). In the three decades which define the film noir period, the threatening side of the nationalist myth invaded the plots by exploring paranoia and social fear. If citizens' daily lives in the postwar years were pervaded by frightening images of Communist invasion and atomic bombs, film noir provided the audience with narratives about individual isolation and social corruption, in a manner that reflected the political anxieties of the era:

The revival of the House of Representatives Committee on UnAmerican Activities (HUAC) after the war and the commencement of its investigation into the Hollywood movie industry in 1947 provides a clear indication of the existence of concern that distinctly unAmerican tendencies lay concealed beneath the surface of ostensibly American institutions and threatened to undermine the core values of the American way of life. Furthermore, social shifts resulting from America's involvement in the war had foregrounded the contradictions which lay behind the idea of America as a classless society -as a land of opportunity in which any person was able to achieve success and status through hard work-and had exposed the real class stratification of American society, thereby destabilizing one of America's key myths. (Chopra-Gant 27) 
As part of a countercultural phenomenon, this film genre soon became the dissident eye with respect to other genres of postwar Hollywood and their optimistic national propaganda. In a sense, film noir articulated the nation's pressing fears and secret desires to confront the problematic state of affairs both internationally and domestically. The aestheticism conventionally comprising film noir "poetics" was merely a formal tool to introduce political and social criticism which challenged the codification of national identity. It is precisely through the interpretation of this film genre as a cultural product testing the nation's hidden anxieties that it is possible to understand film noir as a reflection of a global shift in thinking about the United States of America in connection to the rest of the world after the Second World War. And this is the reason why it is easy to find social, racial, political and sexual conflicts which were completely absent in all other film genres promoted by Hollywood at the time.

In the pre-war period of the New Deal, before the prolific production of films in this noir mood, social crime was explored in gangster films which adopted the traditional organization of male characters in a dialectic of good versus evil. The types of masculinity recreated in this genre were developed within the oppositional structure of the gang leader embodying social decay, and the police acting as the protectors of social order. In this sense, it is easy to understand these narratives as didactic stories which showed the negative consequence of criminality, and the ways society could restore order after chaos through its institutions. Therefore, the plots focused on different types of masculinity in terms of their roles regarding social norms. The hero and the antihero were characterized in opposition concerning their moral attitude towards their social environment, with convenient stress placed on the reasons why a male character could eventually became an evil citizen. Interestingly, the narration of masculine dispute in these films served to highlight some new features in the antihero which connected the gangsters to the image of the self-made man who became increasingly powerful through hard graft. In a time of social reconstruction from national chaos, the gangster became a tragic hero, a citizen who became successful in a hostile world but whose immoral deeds provoked his dramatic death in the end (Warshow). The moral tension created by this ambiguity tended to be resolved with the effective role of the police in preserving social order and the 
Disabled Masculinity as a Metaphor of National Conflict in the Cold War Era: Orson Welles'The Lady From Shanghai (1947)

unavoidable tragic ending of the gangsters in the final scenes (Ross 135-36).

This shift in the male antihero was quite relevant when studying masculinity in film noir in relation to gangster films. Though the new crime films of the 1940s and 1950s were unique in the history of Hollywood because they divorced the plots from any didactic purpose, the so-called "hard-boiled" character adopted many of the features invented for the former antihero regarding his flirtation with criminality as a personal project. However, darkness as a metaphor for social degeneration was unavoidable for all characters in film noir, and the stories did not leave any room for morality or any sense of restoration. Hence, masculinity in its "hardboiled" form differentiated itself from any clear-cut heroic role and was embodied by the existentialist antihero of the postwar period in a social structure void of heroes or moral status which could be of any help.

On the other hand, the formations of masculinity that film noir explored were set within a conventional scenario of sexual conflict, regarding the encounter of the antihero with the femme fatale as a repeated leitmotif. This represents a departure from previous crime films in which the female characters played a secondary role in the stories, as well as a clear transformation of the male protagonist in his process of adapting himself to the hostile world he had to face. Sexuality, and more specifically deviant sexuality, became a thematic axis in these stories, and the mythic power of the spider woman was central in the modification of masculinities on stage. The identification of the monstrous feminine with crime changes the very interpretation of criminality, which was designed to be a sexual drama. Her ambiguous characterization and the enchantment caused by her sexuality within narratives about violence was accompanied by a clear attack against the traditional role of women in nuclear families. There are innumerable interpretations from different fields of film criticism which try to understand the social impact of these fatal women in American society at the time of film noir, with different results, but from the perspective of historicist criticism, this fictional figure can only be interpreted in light of contemporary changes in the lives of American women. From this perspective, the noir femme fatale became a metaphor to express a national threat, that of women's rejection of previous patriarchal roles. As Deborah Walker-Morrison states, 
The widely accepted sociological explanation for the emergence of this spider-woman figure in American noir of the 1940s and early 50 s sees her as a product of the accession of women to positions of greater economic independence [...] on their return, American men, already emotionally scarred by the experience of war, suddenly found themselves having to compete in the workforce with those whose roles had previously been limited to those of sweethearts, wives, and mothers. (25)

This idea is unavoidable when understanding film noir as concerned with a social crisis that was currently debated in postwar America; a conflict which conveyed the partial decomposition of patriarchy and the essential opposition between men and women's role in society. Film noir participated in this cultural scenario and constructed stories about independent women who weakened male power for their own sake. Male characterization, therefore, significantly departed from the patriarchal hegemonic tradition and integrated pathological features with a clear interest in depicting masochistic men, violently assaulted in their virility by the quasi demoniac power of the femme fatale (Krutnik). The strong sexual appeal arising from her body appropriated the narrative line and symbolically organized the plot to connect deviant femininity with all social conflicts within the films, affecting the male characters' physical and moral disabilities. Possibly without intending to do so, film noir accomplished an ideological purpose by questioning hegemonic sexuality and composing narratives with male and female characters who challenged patriarchal conventions.

The bibliography for the figure of the femme fatale is huge. Starting with the appropriation of this issue by feminism and psychoanalysis in the decade of the 1980s, it has continued to grow and mature with differing results of appreciation. The focus on the issue of masculinity in film noir is not as extensive. It emerged in the final decades of the twentieth century as a result of the emergence of Masculinity Studies as a suitable field of research in the 1990s. Despite its brief academic tradition, it is possible to find interesting analyses of the function of male protagonists in film noir leading to various conclusions (Abbot; Chopra-Grant; Krutnik; Straayer; Wager). The major outcome in terms of the genre-gender connection was that the overall presence of hysterical, deficient male characters categorized under the "hard-boiled" trademark form a "grand" 
Disabled Masculinity as a Metaphor of National Conflict in the Cold War Era: Orson Welles'The Lady From Shanghai (1947)

(inherently signified) narrative about the dangerous feminization of American society after the war. ${ }^{1}$

In a sense, the combined components of film noir helped construct a socio-political statement about the nation's weakness intimately connected to the unavailability of proper hegemonic masculinity to embody the empowerment of national superiority.

Returning veterans found that prices had spiked on the home front, that the world had moved on without them, that wives had acquired a new degree of independence and financial security through war work, and that behind the dream of the white house with the picket fence there lurked a nightmarish void hidden from public view. (Dixon 1)

Instead, male characterization in these films adopted an existentialist element by transforming the stories in an unsuccessful quest for the truth that was never to be seen again. Regarding the main protagonist, he was usually depicted as an immature man who was proved inefficient in his quest to become a proper man, a hero in the vein of the conventional hero naturalized by Hollywood films. Perhaps this particularity is the reason for the enormous capacity of film noir to capture the interest of scholars belonging to very different academic disciplines, who finally need to address gender issues for their own arguments. ${ }^{2}$ Yet, what seems to be at stake is that the common message of all approaches points to a certain gender crisis which is found at the center of all noir stories in the history of

\footnotetext{
1 Many scholars have studied this "feminization" of American society from different approaches. What is shared by all these critical interpretations is that feminization is always connected to social and economic crises. Among them, Michael Kimmel locates the first instance of feminization at the very formation of the United States of America as a modern capitalist nation and the emblem of self-made men as the symptom of masculinity as an unstable category which must be constantly proved and tested in terms of success and winnings (37-60).

2 There are some critical approaches which tend to consider the antihero as pertaining to the tradition of Romantic masculinities and link male fragility with stances of French Existentialism or with certain ideas of fatalism as conventional of the postwar environment (Porfirio; Pippin), there are others who categorize the protagonist as an unfixed male identity by using the Oedipus complex from psychoanalysis as an examination tool and studying him as a case of maladjustment (Krutnik), some others even take the character as a psychological case study to see symptoms of hysteria in his behavior (Abbot).
} 
American film, and which is organized by the deconstruction and subversion of patriarchal gender roles inside the different narratives. Nevertheless, the bulk of criticism in terms of gender regarding film noir narratives seems to be unaware of a category intersecting male characterization that is connected with the social unease of the times and is concerned with the confrontation of youth and aging masculinities within the framework of sexual drama. As mentioned above, the young antihero is no more than a puppet in the hands of the fatal woman, while the old man does not represent any kind of wisdom or social stability. Instead, the male counterpart is deemed as nothing more than a disabled person normally characterized by alcoholism, physical incapacities, and infertility. Michael Davidson points out the strong capacity of film noir to reveal the failures in masculine potency in times of strict censorship:

In numerous noir films, a physical or cognitive disability marks a sexual inscrutability, otherwise unspeakable in terms of 1940s and 1950s Production Code directives. Film theory has focused intensively on the mantis-like features of the femme fatale, but it has had less to say about her husband, whose disability serves as a camera obscura on the noir hero's existential wounds. (Davidson 5960)

It is in this sense that the new genre emerged with the task of laying bare some inescapable anxieties about the crisis of masculinity derived from the war experience and its weakened effect on young and old men. The axis of male characterization in film noir establishes that surrounding the spider women are only naïve young men who easily fall into her sexual web or old husbands who are defeated by age, illness, and disability. The decomposition of American hegemonic masculinities is represented by this void which leaves the nation in the hands of empowered and independent women capturing and destroying men's energy.

The inner turmoil of the hero is often mirrored in the grotesque villains whose bodies bear and represent not only their corruption but also the potential collapse of the protagonist as well $[\ldots]$ Fragmented men-like those gone soft-surround the central protagonist as further distorting mirrors, especially in the shape of cripples, men with broken limbs, and little men who try to stand tall. (Forth 390) 
Disabled Masculinity as a Metaphor of National Conflict in the Cold War Era: Orson Welles' The Lady From Shanghai (1947)

\section{ORSON WELLES: SCRUTINIZING AMERICAN POLITICS}

When Orson Welles arrived in Hollywood at the age of 24, he had already built up an image of himself which would be enriched with everything else he did until the moment of his death in 1985. His political commitment and his radical dissidence conditioned his understanding of filmmaking as a modern form of education, an instrument to teach the audience about political issues mixed with a shocking rupture from classical film aesthetics. The first production which made him famous under this light was his version of H.G. Wells' The War of the Worlds in the radio show for the Mercury Theater on the Air in 1938. The dramatic effect of this show on the people listening to the radio became a brand for Welles' political positioning:

Satirizing the American public's susceptibility to radio fear mongers, Welles did the show as a faux newscast, interrupting a phony dance program with breathless bulletins about Martians landing in New Jersey. The fakery was surprisingly convincing to many members of the public, who took to the streets and hills in terror. Angry voices were raised, demanding that Welles be held accountable for his prank. The country's anxiety over the Munich crisis was seen as the underlying cause for the panic Welles triggered; Adolf Hitler described the incident as an example of how easy it was to terrorize the American public, and Welles later claimed that his prank had the serious intent of demonstrating the country's susceptibility to demagoguery. (McBride 30)

This affect he had on people some years before making his first film made him a very attractive figure for Hollywood and provided him with previously unseen freedom in negotiating an arrangement with RKO, which offered him total control over production, direction, and scriptwriting (Fabe 78). The cinema factory was by this time generating its myths and Orson Welles seemed to cope with the profile of film star for the industry (Heptonstall 298). Within two years of signing the contract, Welles broadened his image as a genius with the release of Citizen Kane (1941), showing that he was there to break with Hollywood's narrow worldview:

Part of what made and continues to make Citizen Kane exceptional is 
that it was made with exceptional freedom and control and studio facilities, and this came about because Welles refused to sign a Hollywood contract to take pictures unless he had this control-and because he was formidable enough as a mainstream figure in the late thirties to demand it. People today tend to forget how much of an anomaly Kane was as a "Hollywood picture" when it was initially released in 1941. (Rosenbaum 272)

As a consequence, in the years following the problematic release of this masterpiece, it was difficult for Welles to find a place in Hollywood, and his leftish activism widened the abyss created by his satirical and harsh depiction of William Randolph Hearst, a businessman well known at that time for his power and political influence. Welles was a committed journalist himself and he was aware of the media's responsibility to hold poiliticians and their political projects to account. As Gilmore and Gottlieb state when approaching Welles' position after the war:

Reporters must be part of a broadly partisan effort: "Putting the truth on the offensive is your job." Anything less than that is a capitulation to the status quo, dangerous at a time when democracy -"economic as well as political," Welles reminds us: "Neither has reality without the other"- is not so much a fully achieved reality as a goal that must be strenuously pursued. (113)

In his years as a columnist writing for The New York Post, he explored his ideas on the sovereignty of the people in a true democratic society, stressing his opinion that politicians were irresponsible people who could lead America towards disaster again. He took on this commitment, therefore, as a life stand, and it intersected all his activities, including his career as a filmmaker. As a visionary, Welles understood the role of mass media and cinema in imposing political consciousness over the audience, which he encouraged through artistic experimentation. The case of William Randolph Hearst arose as a perfect target to demonstrate how the press could serve conservatives for their anti-democratic goals. His film depicted the man's manipulative power which was also meant to test Hollywood's ideas about left-wing explorations. He wanted to reveal the function of mediocre films in creating a sense of sweetened unreality for an audience too devoted to passively swallowing their conservative messages. In his articles and letters, he took on the role of spokesman for the fight against racism and anti-Semitism, and he 
Disabled Masculinity as a Metaphor of National Conflict in the Cold War Era: Orson Welles'The Lady From Shanghai (1947)

stood for a pan-cultural America which could deliver justice to minorities and those on the margins. He also became a regular speaker at public events, where he could support his argumentation about the war in Europe and about the necessity of American society to transform itself for the welfare of all its citizens and the rest of the world. In one of these speeches, held in Los Angeles in 1943 for the Annual Education Conference devoted to the issue of "New Techniques and Mass Education." he expressed his full commitment to a fruitful internationalism as the only possible way of solving the international political conflicts of the time:

In this shrinking new world of ours, adult education must first enlist in the war against provincialism. Exactly as long as the proposition that all men are created equal is a faith real enough for men to die for it, educators, which means everyone in possession of the instruments of education, are sworn to the tremendous task of telling people about each other, about their works which are called wisdom and culture [...] It was, he insisted, "a requisite of our victory [...] -and making the dream of inter-American unity come true is less a job for diplomatists that it is for educators. The United Nations are fighting for unified mankind [...]." (Callow 202)

\section{THE LADY FROM SHANGHAI: DISABLED MASCULINITIES AND THE COLLAPSE OF NATIONAL MALE HEROISM}

It is not difficult to understand the attraction which Orson Welles could have felt for the cinematographic universe created by the first noir films. His experience in filmmaking was strongly affected by the expressionistic style and the dark exploration of characters that belong to the film noir landscape. In 1947, when The Lady from Shangai was released, the new genre already accounted for at least fifty films, a period of intense production which significantly coincides with the entrance of the United States of America into the Second World War and the first postwar years. If it is clear that "Noir served as the most authentic version of the inherent corruption and complacency of postwar life, when forced consensus and idealized conformity were prized above all other considerations" (Dixon 1), then it is also evident that at some point in this period, Welles would turn to film noir in order to recreate it and use it for his political purposes. 
Having released Citizen Kane (1941), The Magnificent Ambersons (1942), and The Stranger (1946) for RKO Pictures, Orson Welles took over the project of renovating the noir tradition when he left RKO Pictures and engaged in a new phase in his career working for Columbia. He participated in the adaptation of Sherwood King's 1938 novel If I Die Before I Wake for the script, and controlled all the filming process as director, producer, and leading actor as well. Deeply affected by the negative experience he had suffered because of the conservatism of the previous Hollywood studio (Gonsalves), Welles now had the freedom he needed to compose a complex film with a multilayered narrative to be used to denounce postwar life in America.

Though the film seems to belong to the traditional love triangle plot, The Lady from Shanghai entails a reconfiguration of this conventional narrative by introducing a complex structure of leading and supporting male characters surrounding the femme fatale. Welles uses canonical elements of male rivalry to produce an allegorical organization of masculine types with clear references to the context of American society. It is quite evident that the sexual tension provoked by the female totem is extended here to a historicized scenario in which men's aging, represented by the secondary male characters, symbolizes the collapse of hegemonic heroism and, therefore, the loss of patriotic masculinity so relevant in fostering a sense of national power in the international arena.

In terms of the youth/old husband confrontation, Welles opts to inscribe in their characterization the dialectic which opposes idealistic humanism and neoliberal mercantilism, accompanied by an outstanding debate on how they are rivals in their nationalistic positioning. The male Irish sailor arriving in New York after fighting in the left faction against Franco in the Spanish Civil War is transformed into a spokesman for Welles' political positioning through the sarcastic voice-over comments, which are then transformed into a structural instrument for dramatic irony and peppered throughout the film. Michael O'Hara condenses this cynicism about a wasted world into a Romantic bias about the ancient mariner, the myth of the sailor who challenges national frontiers and lives free in his search for a lost identity. Furthermore, his Irish origins makes him a foreigner in a racist nation, and Welles uses this feature to show how far he is from understanding the new world of American dehumanization. The clash between the sailor's naïve performance and the ironic statements of the voice-over 
Disabled Masculinity as a Metaphor of National Conflict in the Cold War Era: Orson Welles'The Lady From Shanghai (1947)

narration produces a short-circuited text in which images and sounds never match, leaving the audience with no way of discovering the truth.

The opening sequence is a clear example of this technique and leaves no doubt about Michael O'Hara's infantile innocence, a lack of malice that is counteracted by the femme fatale's seductive voice. In the pastoral scene set in Central Park, the protagonist meets Elsa Bannister in a composition that is reminiscent of a fairytale landscape: the antique carriage, the forest, male seduction, and phallic symbols as hints about the sexual plot which is formally hidden. The narrator's voice is meant to insert a counteracting metatext through which the audience is aware of the incapacity of the male youth to see the true nature of the femme fatale from the very beginning. The trapping obliges him to take a trip on board a ship, a luxury yacht owned by Elsa's husband, a voyage from New York to San Francisco via the Panama Canal with a stop-off on the Mexican coast, which gives the narrative some space for the Irish sailor to report on social and racial difference along the journey (Fay and Nieland 169-173).

From here on, the film gets complicated as the male character network, central to the plot, separates the story from the love triangle normalized by film noir and turns the film into an exploration of masculinities in confrontation rather than a simple display of female perversity. In this way, Welles prefers to focus the narration on the figure of Arthur Bannister, the disabled husband and rich lawyer with a reputation for manipulating the law whose professional corruption is hinted at by the constant presence of his associate, George Grisby. On board Circe, as the ship is allegorically called, this character is portrayed as a grotesque person (usually filmed with extreme close-ups using strange camera angles and an unpredictable depth of focus), with a hysterical obsession about atomic bombs and the end of the world. The unconventional relationship between these two male characters, Arthur and Grisby, is one of the most evident innovations of the film as regards the tradition of film noir, since the narrative does not even hint about the reasons for his continuous interference in the family realm, and leaves the door open for interpretations of homosocial connection with the husband, partly breaking with the usual noir triangle (Davidson 66-67).

The struggling dispute between the three male figures takes on ideological characteristics in the different scenes as Welles 
situates them symbolically within the frame to introduce their positions, and in doing so, reveals the deficient masculinities they repesent. If Michael O'Hara embodies the naïve and idealistic young man who cannot match the aggressive and dehumanized world of capitalist America, the partnership of Bannister and Grisby is depicted by distrust and apprehension over their constant suspicion of each other's secret interests. One of these scenes, which is introduced as a moral commentary about this conflict, is set on an Acapulco beach at night. In order to reinforce the opposition between the three characters, Welles includes a monologue from the seaman's mouth, which functions as a didactic parable: Michael O'Hara narrates the story of some sharks which, attracted by the smell of blood, gather around a dead shark and in the ecstasy of the smell, end up eating each other. The image composition situates the Bannisters and Grisby in front of the protagonist, and the intrusive use of extreme close-ups produces an expressionistic depiction of the sense of suspicion that lurks between them; the sweat on their faces, the frowning forehead in Grisby's countenance, and their drunkenness clearly stress a concentration on male affairs divorced from Elsa's stony coldness.

The scene opens with a dialogue addressing human values and human nature, which once again establishes the ideological opposition between Michael O'Hara, the supporter of idealism, and Arthur, who functions as the representative of the social Darwinism of the times. At the end of the sequence, the viewer learns that they are all conscious of their immorality, and all seem to symbolically participate in the massacre symbolized by the sharks. In the middle of the emotional chaos, the young sailor even betrays his ethics, gradually annihilated by his willing subordination to Elsa Bannister's manipulative power.

Within the framework of masculinities in conflict, Welles breaks with the canon of film noir by broadening the characterization of Arthur Bannister, who can be interpreted not as secondary, but as the only one whose character is developed in-depth as the film develops. The husband-figure was invented in the genre with the only function of maximizing the femme fatale's evil, but Orson Welles enriches the scenes in which Bannister plays the leading role to put into his mouth all the political and social issues which he wanted to scrutinize. This is perfectly developed in the sequence following the fairy-tale presentation of the main couple in Central Park, set now in the seaman's hiring hall, where the famous lawyer's crippled body is 
Disabled Masculinity as a Metaphor of National Conflict in the Cold War Era: Orson Welles'The Lady From Shanghai (1947)

seen on the screen for the first time. He is attempting to get Michael O'Hara to take him on board the yacht, and the camera takes a morbid interest in focusing on his disabled legs, his painful movements supported by two canes, and his bird-like emaciated face. While he tries to convince the sailor to accept the job, they have a chat with other sailors about manhood. Among brave and hard bodies, the lawyer seems to be in an inferior position, and the conversation about what a tough guy is provokes a meaningful discussion about masculinity and power. To this question, the sailors reply that there is no tough man by birth, toughness comes with power, but it has nothing to do with physical strength or courage; toughness depends on the different privileges that some men have: "a man with an edge," clearly pointing to money and wealth. ${ }^{3}$

The paradox is displayed in this precise scene of the film: to be a powerful man has nothing to do with being a strong man, and the exaggerated disabilities of Bannister's body are quite evident proof of this. Moreover, the category of social class that makes the lawyer more powerful than the sailors is reinforced in a scene on board Circe where Arthur diminishes and humiliates part of the crew, significantly marked by ethnic difference. That the master reproaches them for their monetary interest in working for him reactivates the dehumanizing aspect of the hierarchical microcosm created on board, and it is used by Welles to include a critical commentary regarding racism and current ideas about white supremacy.

However, the constant confrontation with Michael O'Hara's strong body transforms Bannister's power into a debatable issue, and, though marriage provides the lawyer with the social control of his wife, his paralyzed body makes him an imperfect, impotent man who cannot face his rival's sexual potency. ${ }^{4}$ Conventionally, the love triangle of film noir shows sterile marriages with portrayals of aging and weakened husbands that cannot cope with the femme fatale's

\footnotetext{
3 The "edge" is a signifier that is displaced into several meanings along the narrative: at the beginning it refers to the power of money, but throughout the film the edge is translated into guns, sexual appeal, thirst for revenge, institutional power, the manipulative use of the law, or the supremacy of being white (Abbot, 2002, 125-154). 4 Michael Davidson links this male representation with a historical fact which was contemporary to the film release, by which Welles want to depict the character as having the effects of polio, a disease that affected thousands of men at the time which provoked a sense of lack of virility in the postwar period (Davidson, 2003).
} 
hypersexualized body, but here the prominence of Bannister's body in the most important scenes of the film demonstrates Welles' intention to renovate noir masculinities. The loss of virility takes on the condition of a performance in these scenes and filming techniques are used to construct the idea of emasculation by fragmenting Bannister's body in the same way that traditional film noir does with the female character. In many takes, the canes and feet moving with a mechanical cadence appear on the screen as signifiers of the man, depriving the character of an integral and hegemonic masculinity.

Another key scene in the film shows Bannister defending Michael O'Hara at his murder trial. Welles turns it into a hilarious scene with the lawyer playing games with all elements of the judiciary system for his own sake. Here his exaggerated movements throughout the court; the tension displayed on the accused's face; and the shots taken of the public laughing at Bannister's jokes convey harsh criticism on justice and the exercise of the law in the hands of corrupted lawyers and judges. Welles seems to be denouncing that the American sense of democracy is lost; that hegemonic masculinities upholding the task of the common good are lost; and that there is no possibility of finding heroism on the American land.

And this nihilistic vision captures the audience's attention with the bizarre sequence with which the film concludes. Once Michael O'Hara escapes from the courtroom, he ends up in the Hall of Mirrors at a desolate amusement park. The scene recorded in a surrealistic mood is the climax of a narrative which has been so preoccupied with gender identity and difference by using the metaphor of mirrors to accentuate the myriad of secret selves hidden to the audience until this final moment. The innumerable specular angles create an atmosphere of suspicion and confusion which is inherent to the whole story and serves to lay bare the true nature of the three characters involved: the husband, the wife and the male youth in-between. And once more, the camera focuses on Bannister's disabled legs and the robotic movement which produces a threatening effect on a screen divided into hundreds of parts, all displaying the same image. Welles completes the baroque visual texture with the superposition of close-ups and the full-length images of the bodies of husband and wife, which symbolize one of the thematic lines which runs through the film: the impossibility of being sure about the surface truth in the middle of a web of lies and 
Disabled Masculinity as a Metaphor of National Conflict in the Cold War Era: Orson Welles'The Lady From Shanghai (1947)

secrets. This final scene also constructs the idea of personal corruption as essentially self-destructive, while the antihero becomes a mere observer of the Bannisters' annihilation, and leaves the nightmarish scenario with the only desire of forgetting his foolish love for Elsa. As a mature man, Michael O'Hara feels that there is no way out of the dehumanization caused by the money cult invading American society, and the film ending exhibits a certain sense of pessimism for the lack of brave men to lead the future of American history.

\section{CONCLUSION}

The phenomenon of film noir created a counterculture in the universe of Hollywood which inaugurated a new way of making films. The aesthetic components, which recovered some expressionist techniques, were adopted as formal tools as an excuse to explore social and political issues which were critical to promoting identity at the time. Orson Welles represents in this context the most uncomfortable figure for the political elites governing Hollywood: his social commitment and his ideas about cinema as a means of popular education were a problem for the studios which wanted to construct an idea of national cohesion and success. However, his brilliant accomplishments when making films allowed him to be at ease when he started the production of his first film noir, The Lady from Shanghai, in 1947.

It can be said that Orson Welles retains the main conventions of the genre in his film by recreating the conventional love triangle within a complex criminal plot. However, he renewed the tradition by concentrating on the psychological tragedy rooted in the crisis of masculinity at the very center of the narrative. To elevate the genre to high-brow quality, the allusions to classical mythology, the sarcastic irony placed in the voice-over, the bizarre images, and the continuous use of extreme close-ups to show the characters' irrationality, transform the noir text into a picture of American society after the war experience.

With this idea in mind, Welles modifies the love triangle and introduces a third male character who enriches the exploration of masculinities in conflict by displacing the femme fatale's central focus. Inside the sexual drama, therefore, gender confrontation is designed as an arena for discussing the different categories of 
identity and the power relations established between them. In this sense, it is clear that the most important issue at stake throughout the plot is how the different male characters establish their rivalry in terms of economic, sexual, social, and political power.

Male characterization, then, is expanded in Orson Welles' noir and deepens the film texture by introducing an elaborate narrative about the loss of hegemonic masculinity in a corrupted, decadent society. The explicit and implicit discussions about manhood are enriched by the play of bodies inside the film: young and old, beautiful and strong, perfect and disabled, expressing an endless dialectic about male identity. Among them, the most relevant opposition is represented by Bannister's paralytic body compared to Michael O'Hara's brutal corporeality: the Black Irish with a savage but handsome body and the Greek Jew with a mechanic and sterile body are representative of deficient masculinities which cannot embody the nation's heroism in postwar America. Michael O'Hara has the promise of youth and the physical strength to be a proper man but he is loaded with the negative connotations of the epithet "black" symbolically pointing to ethnic segregation, and his potential as a strong youth is disempowered by his powerlessness when facing the evil forces of mercantilism represented by Arthur Bannister. The famous lawyer exercises his absolute power over people because he can pay for all his personal relations, but he is actually deemed a half-man, with no independence, and with unavoidable difficulties in his movements, obliged to recognize his impotency as a husband. At a point in the history of the United States of America when national identity tried to construct a strong image of a great nation with the mission of saving the world, Welles' vision calls into question the possibility of recovering the pioneers' masculinity which once upon a time embodied the American Dream.

\section{WORKS CITED}

ABBOT, Megan E. The Street Was Mine. White Masculinity in HardBoiled Fiction and Film Noir. Palgrave-Macmillan, 2002.

CALLOW, Simon. Orson Welles: Hello Americans. Vintage, 2006.

CHOPRA-GRANT, Mike. Hollywood Genres and Postwar America: Masculinity, Family and Nation in Popular Movies and Film Noir. Tauris, 2006. 
Disabled Masculinity as a Metaphor of National Conflict in the Cold War Era: Orson Welles' The Lady From Shanghai (1947)

DAVIDSON, Michael. "Phantom Limbs. Film Noir and Disabled Bodies." GLQ: A Journal of Lesbian and Gay Studies, vol. 9, no.1-2, 2003, pp. 56-77.

DIXON, Wheeler Winston. Film Noir and the Cinema of Paranoia. Edinburgh University Press, 2009

FABE, Marilyn. Closely Watched Films: An Introduction to the Art of Narrative Film Technique. California University Press, 2004.

FAY, Jennifer and Justus Nieland. Film Noir. Hard-Boiled Modernity and the Cultures of Globalization. London and New York, Routledge, 2010.

FORTH, Christopher E. "Nobody Loves a Fat Man": Masculinity and Food in Film Noir." Men and Masculinities. vol. 16, no. 4, 2013, pp. 387-406.

GILMORE, James. N. and Sidney Gottlieb. Orson Welles in Focus: Texts and Contexts. Indiana University Press, 2018.

GONSALVEZ, Joshua D. "Reading Race and 'Rita' in The Lady from Shanghai: Decrypting the Mogul, the Star, and the Author." Mosaic, vol. 50, no. 2, 2017, pp.149-169.

HEPTONSTALL, Geoffrey. "The Indelible Signature of Orson Welles's Films." Contemporary Review, vol. 285, no.1666, 2004, pp. 298-302.

HILLIS, Ken. "Film Noir and the American Dream: The Dark Side of the Enlightenment." The Velvet Light Trap, vol.5, no.1, pp. 318

KIMMEL, Michael. The History of Men. Essays in the History of American and British Masculinities. State University of New York Press, 2005

KRUTNIK, Frank. In a Lonely Street. Film Noir, Genre, Masculinity. Routledge, 1991. 
MCBRIDE, Joseph. What Ever Happened to Orson Welles? A Portrait of an Independent Career. The University Press of Kentucky, 2006.

NAREMORE, James. "American Film Noir: The History of an Idea." Film Quarterly, vol. 49, no. 2, 1995-1996, pp. 12-28.

---.More than Night. Film Noir in its Contexts. University of California Press, 1998

PIPPIN, Robert B. Fatalism in American Film Noir. Some Cinematic Philosophy. University of Virginia Press, 2012.

PORFIRIO, Robert. "No Way Out: Existential Motifs in the Film Noir." Sight and Sound, vol. 45, no. 4, 1976, pp. 212-217.

ROSENBAUM, Jonathan. Discovering Orson Welles. University of California Press, 2007.

ROSS, Steven J., editor. Movies and American Society. Oxford, Blackwell Publishers, 2002.

SHRADER, Paul. "Notes on Film Noir." Film Noir Reader, edited by Alain Silver and James Ursini, Limelight Editions, 1999. pp. 53-64.

STRAAYER, Chris (1998) "Femme Fatale or Lesbian Femme: Bound in Sexual Différance." Women in Film Noir, edited by Ann Kaplan, British Film Institute, 1998, pp.153156.

WAGER, Jans B. Dames in the Driver's Seat: Rereading Film Noir. University of Texas Press, 2009.

WALKER-MORRISON, Deborah. "Sex Ratio, Socio-Sexuality, and the Emergence of the Femme Fatale in Classic French and American Film Noir." Film \& History, vol. 45, no. 1, 2015, pp. 25-37. 
Disabled Masculinity as a Metaphor of National Conflict in the Cold War Era: Orson Welles'The Lady From Shanghai (1947)

WARSHOW, Robert. "The Gangster as Tragic Hero." The Inmmediate Experience: Movies, Comics, Theater and Other Aspects of Popular Culture, edited by Robert Warshow, Harvard University Press, 2001, pp. 97-104.

\section{FILMS CITED}

Citizen Kane. Directed by Orson Welles, RKO/Mercury Theatre Productions, 1941.

Dark Passage. Directed by Delmer Daves, Warner Bros. Pictures, 1947.

D.O.A. Directed by Rudolph Manté, United Artists, 1949.

Double Indemnity. Directed by Billy Wilder, Paramount Pictures, 1944.

Fear in the Night. Directed by Maxwell Shane, Pine-Thomas Productions, 1947.

Mildred Pierce. Directed by Michael Curtiz, Warner Bros. Pictures, 1945.

Murder, My Sweet. Directed by Edward Dmytryk, RKO Radio Pictures, 1944.

The Big Combo. Directed by Joseph H. Lewis, Security Pictures/Theodora Productions, 1955.

The Big Heat. Directed by Fritz Land, Columbia Pictures, 1953.

The Dark Corner. Directed by Henry Hathaway. Twentieth Century Fox Film Corporation, 1946.

The Lady from Shanghai. Directed by Orson Welles, Columbia Pictures, 1947. 
The Magnificent Ambersons. Directed by Orson Welles, RKO Radio Pictures, 1942.

The Maltese Falcon. Directed by John Huston, Warner Bros. Pictures, 1941.

The Naked City. Directed by Jules Dassin, Universal International Pictures, 1948.

The Stranger. Directed by Orson Welles, RKO Radio Pictures/ International Pictures, 1946.

Out of the Past. Directed by Jacques Tourneur, RKO Radio Pictures, 1947. 